The Language of Etrusco-Italic Architecture: New Perspectives on Tuscan Temples Author(s): Ingrid Edlund-Berry

Source: American Journal of Archaeology, Vol. 112, No. 3 (Jul., 2008), pp. 441-447

Published by: Archaeological Institute of America

Stable URL: http://www.jstor.org/stable/20627482

Accessed: 09-06-2015 17:52 UTC

Your use of the JSTOR archive indicates your acceptance of the Terms \& Conditions of Use, available at http://www.jstor.org/page/ info/about/policies/terms.jsp

JSTOR is a not-for-profit service that helps scholars, researchers, and students discover, use, and build upon a wide range of content in a trusted digital archive. We use information technology and tools to increase productivity and facilitate new forms of scholarship. For more information about JSTOR, please contact support@jstor.org.

Archaeological Institute of America is collaborating with JSTOR to digitize, preserve and extend access to American Journal of Archaeology. 


\title{
The Language of Etrusco-Italic Architecture: New Perspectives on Tuscan Temples
}

\author{
INGRID EDLUND-BERRY
}

\begin{abstract}
One detail of the so-called Tuscan temple is the Etruscan round moulding, known from Etruria and monuments in Rome. The earliest preserved example (sixth century B.C.E.) comes from S. Omobono in Rome, followed by Satricum, Pyrgi, Ardea, and Tarquinia through the fourth century B.C.E. As Rome expanded its political interests in the third century B.C.E., newly founded colonies were equipped with major temples (Capitolia) that had a Tuscan plan and often Etruscan round mouldings (Sora, Isernia). Beginning in the second century B.C.E., new construction or remodeling of temples often displayed parallel traditions, including a Roman cyma reversa (Paestum) or an Etruscan round podium moulding (Cosa). The presence of the Etruscan round mouldings is not arbitrary. Only when Rome establishes its own architectural language through the cyma reversa moulding do we see that it has shed its dependence on the past and reached its own goals, political as well as architectural.*
\end{abstract}

Thanks to Larissa Bonfante's insightful research on many aspects of Etruscan culture, we can appreciate its significance for a variety of cultural expressions within ancient Italy. As new discoveries are made, and research and reevaluation of Etruscan monuments and artifacts continue, the opportunities for appreciating the complexity of political and social interactions between different groups of people provide ever-increasing challenges. As an example of such a complexity, I focus here on the so-called Tuscan temples and their role as statements of religious and political dominance within Etruria and central Italy.

By way of a recusatio, I stress that the topic here is not the plan or proportions of the Tuscan temple as first discussed by the Roman architect Vitruvius in De archi-

\footnotetext{
*I thank Helen (Ili) Nagy for organizing the panel in honor of Larissa Bonfante on the occasion of her receiving the Gold Medal for Distinguished Archaeological Achievement of the Archaeological Institute of America. I am also grateful to Jane Moore (the University of Texas at Austin) for preparing the illustrations for publication. In this article, I follow Meritt's spelling of "moulding" rather than the AJA style ("molding"), since in her terminology, "moulding" rather than "molding" refers to a curved feature that is part of a building block.

${ }^{1}$ Rowland and Howe 1999, 60-1, fig. 73.

${ }^{2}$ For an overall study of Etruscan temples, see Colonna 2006.

${ }^{3}$ The term "Etruscan round" is used by Meritt (Meritt and
}

American Journal of Archaeology 112 (2008) 441-47 tectura $(4.7 .1-5)^{1}$ and, in his footsteps, by architectural historians and archaeologists through the centuries. Instead, I address one issue-seemingly minute-that had a considerable role in determining the function of the Tuscan temple in different geographical, cultural, and chronological contexts: the Etruscan round moulding.

As is well known, one of the characteristic features of the Tuscan (later, Roman) temple plan was the raised podium, made of cut blocks-with steps at one short end-on which the temple building proper rested. ${ }^{2}$ Whether created to enhance the visibility of the temple structure (e.g., the Capitolium at Ostia) or for some other reason, such as the leveling of the ground, the raised platform is usually all we have left of such onceimpressive monuments dedicated to the deities of an Etruscan or Etrusco-Italic city.

Depending on the use of local stone and the layout of the terrain, these platforms or podia consisted of several layers of stone on the outside, with supporting stretches of wall or rubble occupying the center. Seen from a distance, the platform provided the level foundation for the building proper and was often but not always marked with a rounded moulding (the socalled Etruscan round), indicating the transition between the supporting podium and the foundation for the temple building. ${ }^{3}$

The earliest preserved evidence of a Tuscan-type temple with such mouldings comes from the site of $\mathrm{S}$. Omobono, below the Capitoline Hill in Rome. There, in spite of very complicated excavations underneath the present church, small sections of two phases of the archaic temple podium can be documented. ${ }^{4}$

Edlund-Berry 2000). This type of moulding is often referred to as a toro (torus in Latin) in Italian texts, and its shape is different from that of the Greek ovolo (Meritt and Edlund-Berry 2000, xiii). Meritt grappled with the use of "Etruscan" for this type of moulding, since it occurs in areas that were inhabited primarily by Etruscans as well as in areas that were dominated by speakers of Latin and other central Italian languages.

${ }^{4}$ The precise dates of the two phases of this temple are disputed, but they fall within the early and late sixth century B.C.E., respectively (Gjerstad 1960, 380-86, figs. 245, 246; Pisani Sartorio and Virgili 1979; Comune di Roma 1989; Colonna 1991; Musei Capitolini 2005, 132-33; Colonna 2006, 154-55; Winter [forthcoming]). 
Since this podium is so poorly preserved, it is difficult to evaluate exactly how the round moulding was cut (fig. 1), ${ }^{5}$ but the profile suggests that the bottom block projected beyond the round and that the intervening blocks were set further back. In the second phase of the same temple, the single round developed into a double and was set firmly on one projecting block below.

As documented by Meritt, these round mouldings express a practice that is totally foreign to Greek architectural traditions in terms of placement and execution, not to mention the use of a platform or podium. The purpose of the moulding was to provide the transition from one set of blocks to another, and the profile was executed by cutting back from the vertical line of the blocks until the desired curve had been achieved.

Since the Etruscans were not known for conformity or predictability in terms of their architecture-or anything else for that matter-it should not surprise us that there is a definite lack of consistency in the use (or non-use) of these mouldings. Due to the arbitrary status of preservation, we should probably not assign too much significance to the fact that the archaic temple at S. Omobono represents the earliest preserved podium mouldings to date.

A podium moulding similar to that of the first type from S. Omobono-with a vertical podium profile crowned by a round-may also be found in Temple I at Satricum, south of Rome (also known as the "sacellum" or Temple 0 ), and can be dated to 550-540 B.C.E. ${ }^{6}$ A rounded fragment of such a moulding was found there in the late 19th-century excavations. In the excavation report, published in Notizie degli scavi di antichità for $1896,{ }^{7}$ the fragment was reconstructed as part of a sequence placed between an angular block and a hawksbeak moulding underneath (fig. 2). More recently, however, Colonna has proposed a reconstruction that suggests that the round was protruding from a vertical set of blocks forming the podium. ${ }^{8}$

A similar reconstruction has been suggested, also by Colonna, for fragments found at Temple A at Pyrgi, the Etruscan sanctuary on the coast north of Rome. There,

\footnotetext{
${ }^{5}$ The mouldings from S. Omobono are discussed briefly in Shoe (1965, 22 n. 5) but are not illustrated; see also Meritt and Edlund-Berry 2000, 22 n. 5. I have based the illustrations in this article on Shoe's drawings whenever possible because they represent a consistent technique of recording. For the sake of clarity, an outline of the profile (facing left whenever possible) has been superimposed on the actual blocks of the temple podia, but because of the small scale of the illustrations, the preservation of the stones, and sometimes the angle of the photograph, the agreement is not perfect. I refer to Meritt (Meritt and Edlund-Berry 2000, xviii-xix) and EdlundBerry (2005) for a discussion of the principles of measuring
}

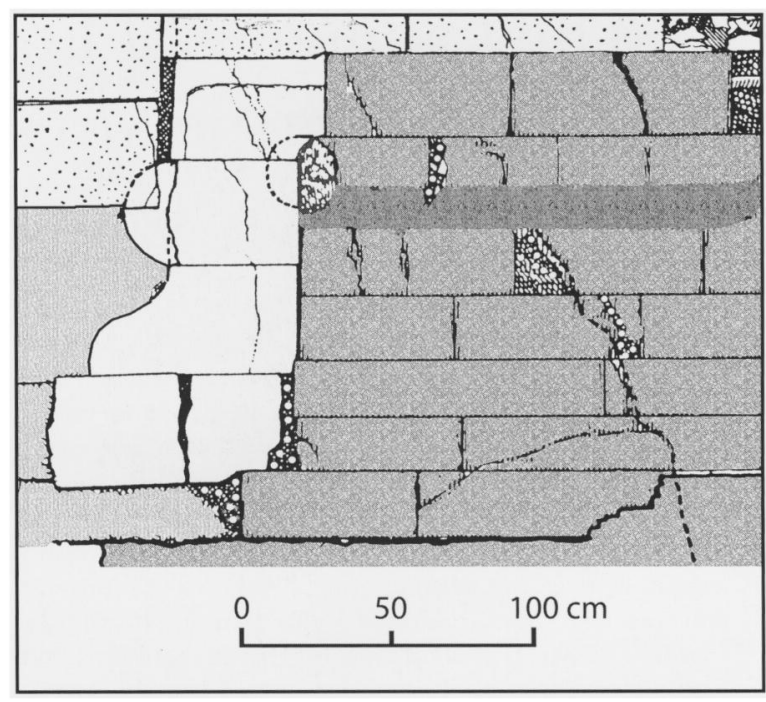

Fig. 1. Profile drawing of archaic temples at S. Omobono, Rome (modified from Gjerstad 1960, figs. 245, 246; Colonna 1991, fig. 1; Comune di Roma 1989, pl. 2).

two fragmentary blocks-one of which preserves an Etruscan round moulding-have been assembled to form part of the podium of this Tuscan temple, dated ca. 460 B.C.E. (fig. 3) ${ }^{9}$

The second type of temple foundation from S. Omobono-with a low podium marked with large, curved rounds-preserves the type of moulding that becomes the hallmark of Etruscan architecture, seen not only in temple podia but also in altars such as those from Lavinium, Orvieto, and Fiesole. ${ }^{10}$ The chronologically earliest such temple podium, following the temple from S. Omobono, comes from Ardea, a town to the south of Rome known for its city wall and several temples. ${ }^{11}$ One of these temples, known as Casalinaccio or Civitavecchia, shows a podium with massive Etruscan round mouldings on the preserved short and long sides (fig. 4). It is commonly dated to the sixth century B.C.E., but a later date of 480 B.C.E. has also been suggested by Colonna. ${ }^{12}$

\footnotetext{
mouldings and illustrating them in full scale.

${ }^{6}$ Barnabei and Cozza 1896, 32, fig. 4; De Waele 1997; Meritt and Edlund-Berry 2000, 86-8, XXIII.3, XXIII.4; Colonna 2005.

${ }^{7}$ Barnabei and Cozza 1896.

${ }^{8}$ Colonna 2005, 112.

${ }^{9}$ Colonna et al. 1970, 43, fig. 31 .

${ }^{10}$ Meritt and Edlund-Berry 2000.

${ }^{11}$ Morselli and Tortorici 1982, 91-3; Meritt and EdlundBerry 2000, 84-6, XXIII.1, XXIII.2. For a view of the Etruscan round, see Meritt and Edlund-Berry 2000, xvi, fig. C.

${ }^{12}$ Colonna 1984, 409.
} 


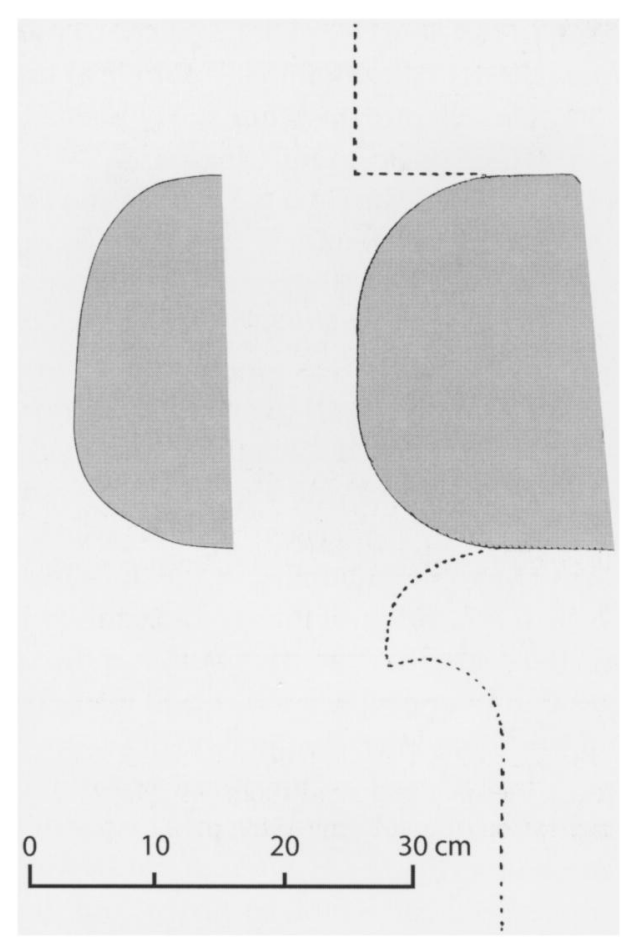

Fig. 2. Temple podium at Satricum (after Barnabei and Cozza 1896, fig. 4, right; Meritt and Edlund-Berry 2000, 86-8, XXIII.3, left).

The largest of all Etruscan temples outside Rome is the early fourth-century B.C.E. version of the Ara della Regina temple at Tarquinia. ${ }^{13}$ It is located on the city hill, and the different phases of the temple emphasize its dominant location and increasingly elaborate plan and decoration. In addition to the striking terracotta decoration, including the famous horses, the podium of the temple was marked by large, highly visible Etruscan round mouldings along the sides and front (fig. 5).

As suggested by these examples, the so-called Tuscan temple with the accompanying Etruscan round podium mouldings spread chronologically from the sixth to the early fourth century B.C.E. in locations ranging from Ardea and Satricum in Latium to Rome at the border between Latium and Etruria and to Pyrgi and Tarquinia in southern Etruria (fig. 6). Although the exact cult and function are not clearly established for all these temples (e.g., at Ardea), some definitely

\footnotetext{
${ }^{13}$ Meritt and Edlund-Berry 2000, 89-90, XXV.2, XXV.3, fig. 16; Bonghi Jovino 2001; Bagnasco Gianni 2002; Colonna 2006, 161-63, fig 8.34.

${ }^{14}$ Ghetti and Pagliardi 1980; Tanzilli 1998; Meritt and Edlund-Berry 2000, xxiii; Mezzazappa 2003. I thank Alessan-
}

constitute the major temple of the city (e.g., at Satricum and Tarquinia). While there are great variations in building material, temple plans, and details of the mouldings, there is no question that this temple type represented something that was easily recognizable by others (e.g., the Greeks further south or the Celts to the north) as distinctly Etrusco-Italic.

It is within this framework that we should see the next phase in the use of the moulding-decorated Tuscan temples. As Rome expanded its political interests outside the familiar areas of Etruria and Latium, newly founded colonies were equipped with major temples (Capitolia) that are clearly identified by their location and Tuscan plan and usually sporting Etruscan round mouldings.

Possibly the earliest example is found at Sora in the Liris Valley, south of Rome, which became a Latin colony in 303 B.C.E. ${ }^{14}$ A temple podium with large Etruscan round mouldings is preserved here underneath the cathedral of Santa Maria Assunta (fig. 7). The same phenomenon occurs at Isernia, further to the east, where a Latin colony was established in 263 B.C.E. ${ }^{15}$ The podium of the main temple preserves a double Etruscan round moulding, today incorporated into the foundations of the cathedral.

Although not officially a colony, the Sabine area around Cascia, in today's southern Umbria, came under Roman influence after 290 B.C.E. ${ }^{16}$ The seemingly isolated site of Villa S. Silvestro is located in the

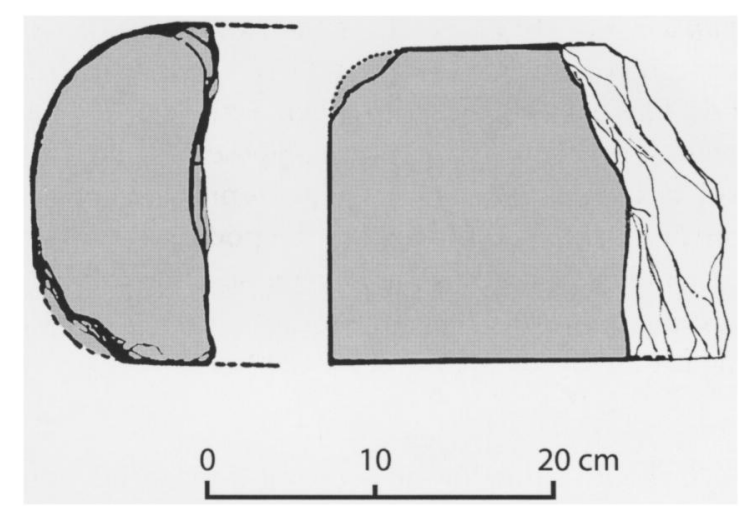

Fig. 3. Podium of Temple A at Pyrgi (after Colonna et al. 1970, fig. 30).

dra Tanzilli for permission to include the photograph of the moulding (see fig. 7) and for her interest in this project.

${ }^{15}$ Diebner 1979, 22-4; Meritt and Edlund-Berry 2000, 92, LXXVI.1, fig. 19.

${ }^{16}$ Bendinelli 1938; Stalinski 2001a, 2001b. 


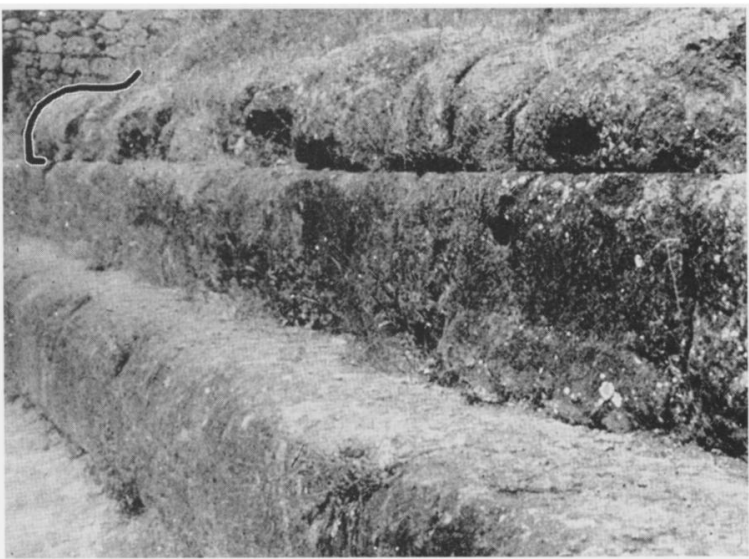

Fig. 4. Podium of the Casalinaccio temple at Ardea (after Meritt and Edlund-Berry 2000, 84-6, XXIII.2 and photograph).

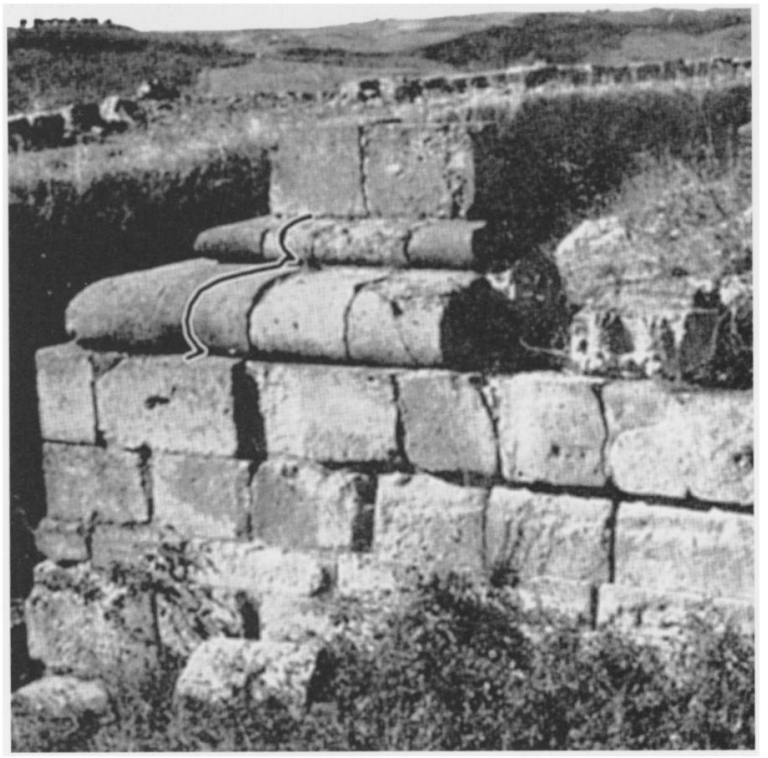

Fig. 5. Podium of the Ara della Regina at Tarquinia (after Meritt and Edlund-Berry 2000, 89-90, XXV.3 and photograph).

north-south valley to the south of Cascia; this valley provides a major access route in this mountainous region, which is subject to many devastating earthquakes.

\footnotetext{
${ }^{17}$ Meritt and Edlund-Berry 2000, 90-2, XXV.5, fig. 18.

${ }^{18}$ Brown 1980. As pointed out by Fentress (2003, 13-32), the material evidence for the earliest phase of the colony is virtually nonexistent; see also Taylor 2002.

${ }^{19}$ Pedley 1990, 113-28.

${ }^{20}$ Bispham 2006, 96-104.
}

The present-day church at Villa S. Silvestro preserves the foundations of the podium of a temple whose hefty mouldings fit well into the sequence of major Tuscan temples with Etruscan rounds (fig. 8). ${ }^{17}$

The Latin colonies at Cosa in Etruria ${ }^{18}$ and Paestum in Campania, ${ }^{19}$ both founded in 273 B.C.E., provide an interesting example of Roman architectural sensitivity to the original settlers of these areas, as well as an indication of the direction of Roman architecture as it comes into its own. Of the two, Cosa was laid out ex novo with a grid plan designating the public spaces, the forum, and the arx (the high point for sacred activities). Although the earliest form of worship and presence of temple buildings on the arx are subject to debate, it was not until the second century B.C.E., at least $\mathbf{1 0 0}$ years after the foundation of the colony, that a Capitolium proper was erected (although the identification has been doubted by Bispham), ${ }^{20}$ decorated with masses of architectural terracottas, and adorned with an easily recognizable Etruscan round base moulding (fig. 9). As pointed out by Meritt, its closest parallel is the temple at Ardea, and the question we have to ask is whether the Roman architect intentionally used an archaizing form of moulding for this "Tuscan" temple in Roman clothing. ${ }^{21}$

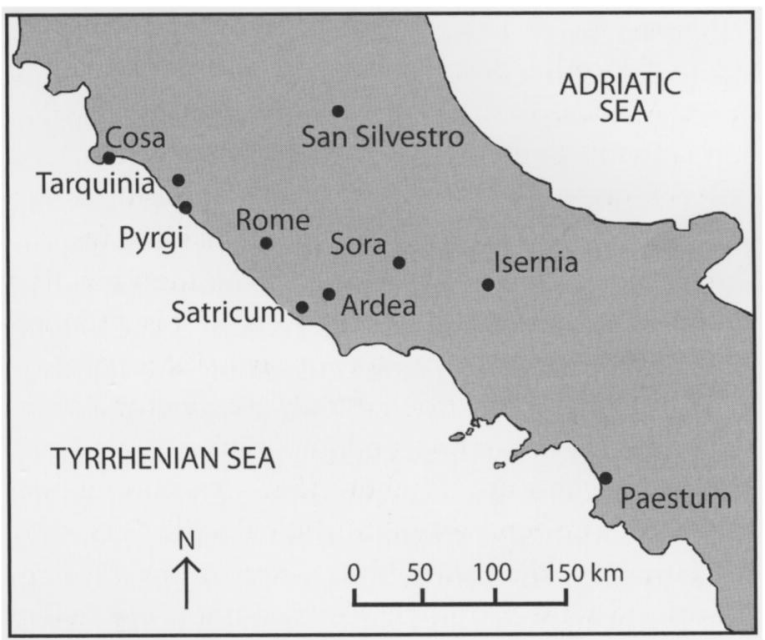

Fig. 6. Map of Etruria and central Italy (drawing by I. EdlundBerry and J. Moore).

\footnotetext{
${ }^{21}$ Meritt and Edlund-Berry 2000, 21, 88, XXV.1, fig. 14. The reconstruction of the podium shown in Brown et al. (1960, 70 , fig. 47) suggests that it may have consisted of a foundation course underneath a rounded base moulding and three rows of cut rectangular blocks, crowned by a matching round moulding, with a total height of almost $3 \mathrm{~m}$.
} 
The scene at the twin colony at Paestum is quite different. The colony here was placed on Greek and Samnite soil, and the city plan was adapted to incorporate the already existing majestic Greek temples. A rectangular forum in the center of the city would seem to be the logical place for a Roman-type temple, but such a temple was not erected until well into the colony's existence-as late as 200 B.C.E. or even toward the end of the second century B.C.E. ${ }^{22}$ The temple that we see today may or may not have been a Capitolium proper (the cult of Bona Mens is one of the options), but aside from the issue of the cult, this temple shows the development in Roman thinking from the old and oldfashioned generic Etrusco-Italic round to something that can be called Roman architecture proper. Thus, the podium mouldings reflect the cyma reversa form (fig. 10), which seems to have developed in Rome and Latium as early as the third century B.C.E. (Temple C, Largo Argentina, Rome), and then spread throughout Italy as part of an architectural language that we can finally call Roman in its own right. ${ }^{23}$

This brief overview suggests that the presence of the Etruscan round mouldings on temple podia is not arbitrary and that it alludes to the importance of the building in terms of its function as a major temple. However, we must tread carefully in identifying such major temples as Capitolia (i.e., Rome-generated temples to the Capitoline triad, including Jupiter) that emulated the plan and appearance of the Capitoline temple in Rome. Because of the often complicated excavation and reconstruction history of these temples, it is difficult to ascertain whether a temple had one or more cellas or other combination of rooms. Moreover-as can be expected due to the lack of inscriptions, votives, or other indicators-the identification of the temples rests on assumptions (if it is a Capitolium, the main deity is Jupiter) or on an interpretation of the decorative material, usually architectural terracottas adorning the roof and pediments.

At the same time, I believe that a careful analysis of the Tuscan temples in all their details, including the base or podium mouldings, can add new insight into the discussion of the Romanization of ancient Italy. While not too long ago the existence of such a temple was seen as a clear indication of the presence of Romans and Roman political domination, current research is viewing the interaction between Romans and non-Romans in Italy with new eyes. ${ }^{24}$ By focusing on all of Italy, the boundaries between dominance and

\footnotetext{
L.4.
}

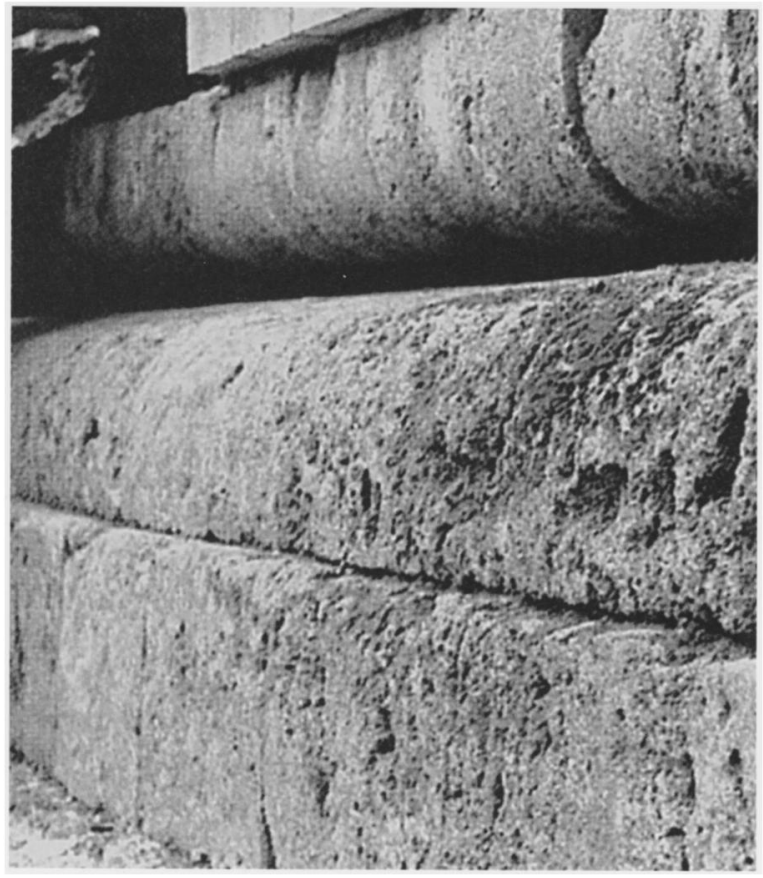

Fig. 7. Temple podium of Santa Maria Assunta in Sora (after Tanzilli 1998, 48).

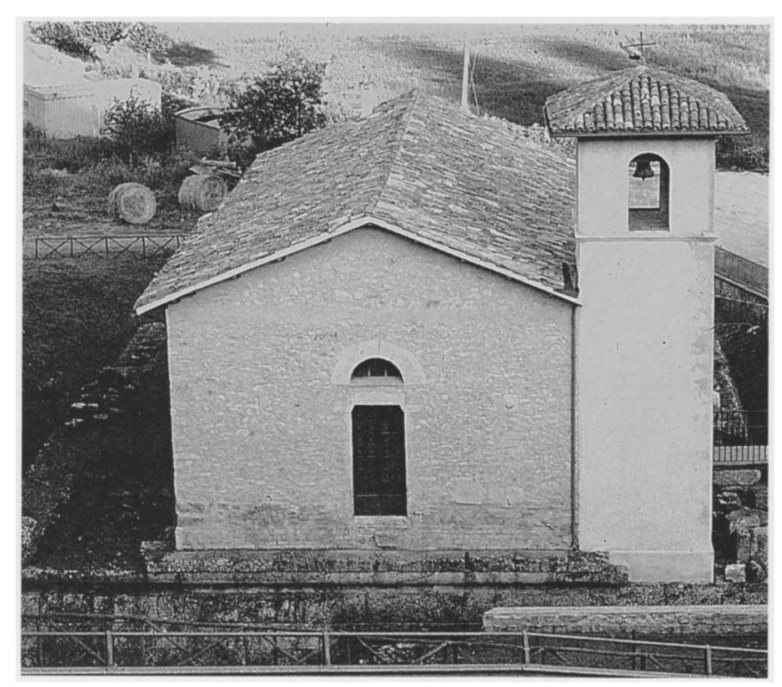

Fig. 8. Villa S. Silvestro church.

subjection are becoming more fluid, and the power of Rome can be viewed as a process of give and take. It is in this regard that the Tuscan temple plan, with its decoration and mouldings, can be seen as created

\footnotetext{
${ }^{23}$ Meritt and Edlund-Berry 2000, xxii-xxv.

${ }^{24}$ E.g., Bispham 2006; Bradley 2006.
} 


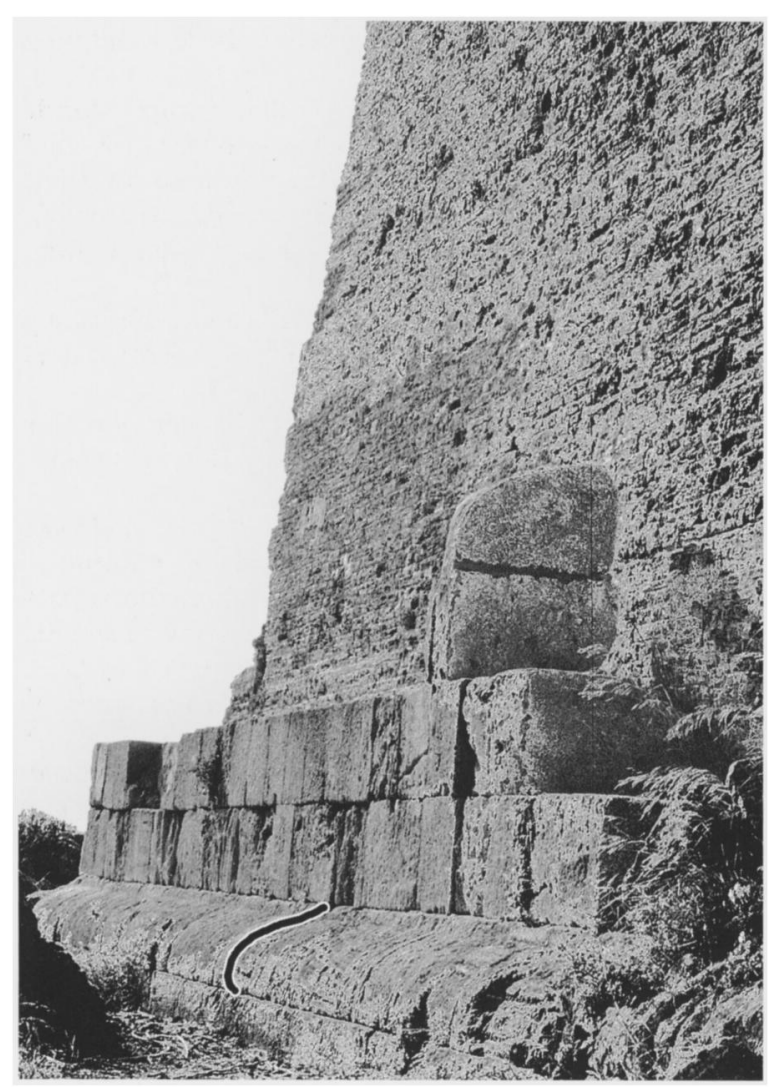

Fig. 9. The temple podium at Cosa (after Meritt and EdlundBerry 2000, 88, XXV.1 and photograph).

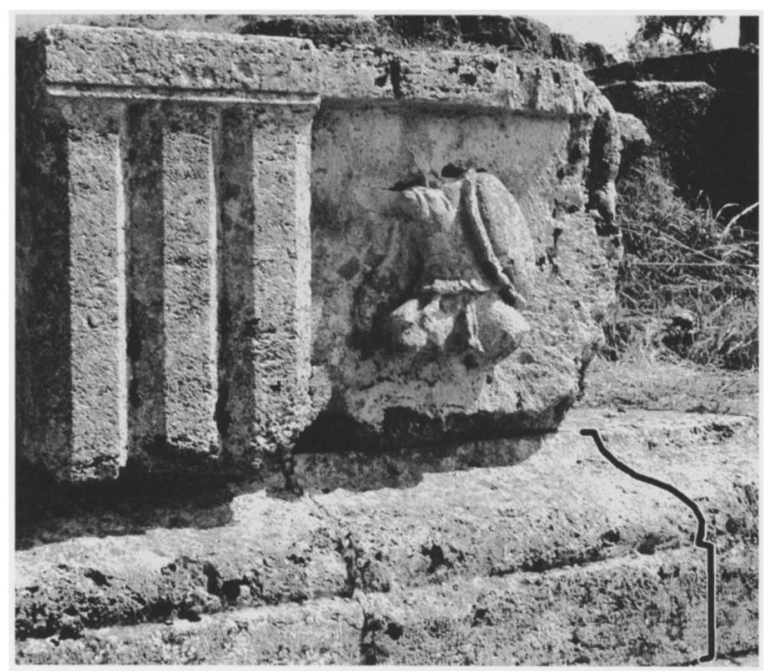

Fig. 10. Podium of the temple at Paestum (after Meritt and Edlund-Berry 2000, 158, L.4 and photograph). within the Etrusco-Italic sphere and was used there successfully. ${ }^{25}$ Ultimately, it was one city (Rome) that followed the tradition of political and cultural expansion that was instigated by the Etruscans who had spread their interests as far as Marzabotto in the north and Capua in the south. By so doing, the Romans used a well-known temple form to shift the emphasis from the Etrusco-Italic tradition to the one that came to be regarded as representing Rome and Rome only.

\section{DEPARTMENT OF CLASSICS}

THE UNIVERSITY OF TEXAS AT AUSTIN

AUSTIN, TEXAS 78712

IEMEB@MAIL.UTEXAS.EDU

\section{Works Cited}

Bagnasco Gianni, G. 2002. "Il santuario dell'Ara della Regina." In Sviluppi recenti nella ricerca antichistica, edited by V. de Angelis, 363-78. Milan: Cisalpino.

Barnabei, F., and A. Cozza. 1896. "Conca: Di un antico tempio scoperto presso Le Ferriere nella tenuta di Conca, dove si pone la sede della città di Satricum." NSc:23-48.

Bendinelli, G. 1938. "Cascia: Monumentale tempio etruscoromano scoperto in frazione Villa San Silvestro." $N S c$ : 141-58.

Bispham, E. 2006. "Coloniam deducere. How Roman was Roman Colonization During the Middle Republic?” In Greek and Roman Colonization: Origins, Ideologies and Interactions, edited by G. Bradley and J.-P. Wilson, 73-160. Swansea: The Classical Press of Wales.

Bonghi Jovino, M. 2001. "Santuario dell'Ara della Regina: Acquisizioni e problemi." In Tarquinia Etrusca: Una nuova storia, edited by A.M. Moretti Sgubini, 45-9. Rome: L'Erma di Bretschneider.

Bradley, G. 2006. “Colonization and Identity in Republican Italy." In Greek and Roman Colonization: Origins, Ideologies and Interactions, edited by G. Bradley and J.-P. Wilson, 161-87. Swansea: The Classical Press of Wales.

Brown, F.E. 1980. Cosa: The Making of a Roman Town. Ann Arbor: University of Michigan Press.

Brown, F.E., E.H. Richardson, and L. Richardson, Jr. 1960. Cosa II: The Temples of the Arx. MAAR 26. Rome: American Academy in Rome.

Colonna, G. 1970. "Il tempio A." In Pyrgi: Scavi del santuario etrusco (1959-1967), edited by G. Colonna et al., 23-47. NSc 24, suppl. 2. Rome: Accademia nazionale dei Lincei.

- 1984. "I templi del Lazio fino al V secolo compreso.” Archeologia laziale 6:396-411.

- 1991. "Le due fasi del tempio arcaico di S. Omobono." In Stips Votiva: Papers Presented to C.M. Stibbe, edited by M. Gnade, 51-9. Amsterdam: Allard Pierson Museum.

. 2005. "Architettura e urbanistica: A proposito del tempio di Mater Matuta a Satricum." In Omni pede stare:

${ }^{25}$ This is not the place to discuss any possible “outside" influences (see, e.g., Naso 1998; Edlund-Berry 2002-2003). 
Saggi architettonici e circumvesuviani in memoriam Jose de Waele, edited by S.T.A.M. Mols and E.M. Moormann, 111-15. Studi della Soprintendenza archeologica di Pompei 9. Naples: Electa Napoli and Ministero per i Beni e le Attività Culturali.

. 2006. "Sacred Architecture and the Religion of the Etruscans." In The Religion of the Etruscans, edited by N.T. de Grummond and E. Simon, 132-68. Austin: University of Texas Press.

Comune di Roma. 1989. Il viver quotidiano in Roma arcaica. Rome: Edizioni Procom.

De Waele, J. 1997. "Cronologia ed architettura dei templi della Mater Matuta a Satricum.” Meded 56:69-84.

Diebner, S. 1979. Aesernia-Venafrum. Rome: Giorgio Bretschneider.

Edlund-Berry, I.E.M. 2002-2003. "Etruscan Architectural Traditions: Local Creativity or Outside Influence?" EtrStud 9:37-43.

2005. "Architectural Theory and Practice: Vitruvian Principles and 'Full-Scale Detail' Architectural Drawings." MAAR 50:1-13.

Fentress, E. 2003. Cosa V: An Intermittent Town: Excavations 1991-1997. MAAR Suppl. 2. Ann Arbor:American Academy in Rome and University of Michigan Press.

Ghetti, M.L., and N. Pagliardi. 1980. "Sora: Scavo presso la chiesa cattedrale di Santa Maria Assunta.” Archeologia laziale 3:177-79.

Gjerstad, E. 1960. Early Rome. Vol. 3. Lund: Gleerup.

Meritt, L.S., and I.E.M. Edlund-Berry. 2000. Etruscan and Republican Roman Mouldings. Philadelphia and Rome: The University Museum Publications and the American Academy in Rome.

Mezzazappa, S. 2003. "La forma della città di Sora e I suoi santuari." In Santuari e luoghi di culto nell'Italia antica, edited by L. Quilici and S. Quilici Gigli, 99-104. Atlante Tematico di Topografia Antica 12. Rome: L'Erma di Bretschneider.

Morselli, C., and E. Tortorici. 1982. Ardea. Forma Italiae 16(1). Florence: Sansoni.
Musei Capitolini. 2005. Musei Capitolini: Guida. Exhibition catalogue. Milan: Electa.

Naso, A. 1998. "I tumuli monumentali in Etruria Meridionale: Caratteri propri e possibili ascendenze orientali." In Archäologische Untersuchungen zu den Beziehungen zwischen Altitalien und der Zone nordwärts der Alpen während der frühen Eisenzeit Alteuropas, 117-53. Regensburg: Universitätsverlag Regensburg.

Pedley, J.G. 1990. Paestum. London: Thames \& Hudson.

Pisani Sartorio, G., and P. Virgili. 1979. "Area sacra di S. Omobono." Archeologia laziale 2:41-5.

Rowland, I.D., and T.N. Howe, eds. 1999. Vitruvius: Ten Books on Architecture. Cambridge: Cambridge University Press.

Shoe, L.T. 1965. Etruscan and Republican Roman Mouldings. $M A A R$ 28. Rome: The American Academy in Rome.

Stalinski, A. 2001a. "Maestranze etrusche in territorio italico? C. Caslanius Volsiniese ed il grande santuario di Villa S. Silvestro (PG)." In Gli Umbri del Tevere, edited by G.M. Della Fina, 261-92. AnnFaina 8. Orvieto: Fondazione per il Museo Claudio Faina.

2001b. Il ritrovamento di "Valle Fuino" presso Cascia: Analisi storico-culturale intormo ad un deposito votivo in alta Sabina. MemPontAcc Ser. 3 in $8^{\circ}$, vol. 5. Rome: Quasar.

Tanzilli, A. 1998. La cattedrale di Sora. Sora: Edigrafital.

Taylor, R. 2002. "Temples and Terracottas at Cosa." AJA 106 (1):59-83.

Theodorescu, D. 1989. "Le forum et le temple 'doriquecorinthien' de Paestum: Une experience pré-vitruvienne." In Munus non Ingratum: Proceedings of the International Symposium on Vitruvius' De Architectura and the Hellenistic and Republican Architecture, Leiden 20-23 January 1987, edited by H. Geertman and J.J. de Jong, 114-25. Leiden: Stichting Bulletin Antieke Beschaving.

Winter, N.A. Forthcoming. Symbols of Wealth and Power: Architectural Terracotta Decoration in Etruria and Central Italy, 640-510 B.C. Ann Arbor: University of Michigan Press. 